\title{
Identification of coryneform bacteria and related taxa by Fourier-transform infrared (FT-IR) spectroscopy
}

Microbial Ecology Group, Department of Basic Biological Sciences, Technical University of Munich, Weihenstephaner Berg 3, D-85350 Freising, Germany

\author{
Helene Oberreuter, Herbert Seiler and Siegfried Scherer \\ Author for correspondence: S. Scherer. Tel: +498161 713516. Fax: +498161714512. \\ e-mail: siegfried.scherer@1rz.tum.de
}

\begin{abstract}
An extensive Fourier-transform infrared (FT-IR) spectroscopy database for the identification of bacteria from the two suborders Micrococcineae and Corynebacterineae (Actinomycetales, Actinobacteria) as well as other morphologically similar genera was established. The database consists of averaged IR spectra from 730 reference strains, covering 220 different species out of $\mathbf{4 6}$ genera. A total of 192 species are represented by type strains. The identity of 352 reference strains was determined by comparative 16S rDNA sequence analysis and, if necessary, strains were reclassified accordingly. FT-IR frequency ranges, weights and reproducibility levels were optimized for this section of high-G+C Gram-positive bacteria. In an internal validation, $98.1 \%$ of 208 strains were correctly identified at the species level. A simulated external validation which was carried out using 544 strains from 54 species out of 16 genera resulted in a correct identification of $87 \cdot 3 \%$ at the species level and $\mathbf{9 5 . 4} \%$ at the genus level. The performance of this identification system is well within the range of those having been reported in the literature for the identification of coryneform bacteria by phenotypical methods. Coryneform and related taxa display a certain degree of overlapping distribution of different taxonomical markers, leading to a limited differentiation capacity of non-genotypical identification methods in general. However, easy handling, rapid identification within $25 \mathrm{~h}$ starting from a single colony, a satisfactory differentiation capacity and low cost, render FT-IR technology clearly superior over other routine methods for the identification of coryneform bacteria and related taxa.
\end{abstract}

Keywords: coryneform bacteria, Micrococcineae, Corynebacterineae, FT-IR spectroscopy, identification

\section{INTRODUCTION}

Coryneform bacteria and related taxa occur almost everywhere on living and non-living matter in the environment, in soil, on cellulosic plant fibres (Lednická et al., 2000), on mammals, on smeared cheeses

\footnotetext{
Abbreviations: $D$, spectral distance; FISH, fluorescence in situ hybridization; FT-IR, Fourier-transform infrared; TGGE, temperature-gradient gel electrophoresis; UPGMA, unweighted pair group method algorithm.

A list of coryneform and related or morphologically similar species contained in the FT-IR spectral identification database is available in IJSEM Online (http://ijs.sgmjournals.org). A frequently updated reference spectra library can be obtained from the authors.
}

(e.g. Seiler, 1986; Schubert et al., 1996; Bockelmann et al., 1997; Kollöffel et al., 1997; Valdés-Stauber et al., 1997; Carnio et al., 1999), even in subsurface sediments (Crocker et al., 2000), and in Antarctic samples (Junge et al., 1998; Tindall et al., 2000). Several strains or species are classified as opportunistic or obligate human pathogens (for review see Funke et al., 1997a) as well as animal and plant pathogens (Holt et al., 1994). Identification of these high-G + C Gram-positive bacteria is therefore not only of ecological and technological, but also of medical relevance.

Among the methods applied for classification of coryneform bacteria and related taxa in recent years are analyses of polyamine patterns (Altenburger et al., 
1997; Busse \& Schumann, 1999) or fatty acids (Kämpfer \& Kroppenstedt, 1996), numerical taxonomic analysis (Kämpfer et al., 1993) and assessment of the heterogeneity of partial 16S rRNA sequences by temperature-gradient gel electrophoresis (TGGE) (Felske et al., 1999). These methods have proven to be valuable but somewhat limited tools for characterization and differentiation of the organisms studied. Other methods have also been reported which placed more emphasis on the identification capability for coryneform genera: analysis of physiological characteristics by the BIOLOG Identification System (Lindenmann et al., 1995), the API (RAPID) Coryne database (Funke et al., 1997b) or the RapID CB Plus system (Funke et al., 1998), comparative 16S rDNA sequence analysis (Bockelmann et al., 1997), the use of genus-specific oligonucleotide probes (Kollöffel et al., 1997) and fluorescence in situ hybridization (FISH) as well as colony hybridization for the analysis of cheesesurface bacteria (Kollöffel et al., 1999). Not all of these methods have provided satisfactory results and they are either too laborious and time-consuming to be performed on a routine basis with respect to the molecular methods, or the costs per sample are high, which is the case with commercially available identification systems for the analysis of physiological properties.

Originally introduced by Naumann and co-workers (Helm et al., 1991; Naumann et al., 1994), Fouriertransform infrared (FT-IR) spectroscopy is a fast technique for classification and identification of microorganisms (e.g. Holt et al., 1995; Goodacre et al., 1998; Kümmerle et al., 1998; Timmins et al., 1998). Moreover, it is a valuable tool for rapid screening of environmental isolates (Tindall et al., 2000). The method would gain more attraction if an extensive database were available for the identification of unknown strains, since FT-IR is a very cost-efficient technique which allows a rapid and simple identification of micro-organisms within $25 \mathrm{~h}$ (Kümmerle et al., 1998).

Actinomycetes have been investigated by FT-IR previously. Haag et al. (1996) have placed their emphasis on strains from the families Thermomonosporaceae, Streptosporangiaceae, Micromonosporaceae and Streptomycetaceae while including a few strains from different families from the Corynebacterineae as well. Klatte (1995) has studied numerous species from the two genera Corynebacterium and Rhodococcus in detail. However, these investigations have not resulted in comprehensive databases and did not allow us to conclude on the capacity of this method to identify unknown strains.

In 1997, Stackebrandt et al. established a novel hierarchic classification system for actinomycetes, the class of the Actinobacteria (high-G $+\mathrm{C}$ Gram-positive bacteria) (Stackebrandt et al., 1997). This taxonomy was recently updated to accommodate new taxa of this quickly expanding group of bacteria (Stackebrandt \&
Schumann, 2000). Based on this classification system, a spectral database consisting of reference strains from 46 genera out of the two suborders Micrococcineae and Corynebacterineae (order Actinomycetales) was established which allows the rapid and simple identification of isolates of this taxonomic group. Morphologically similar taxa such as strains from the genus Staphylococcus were included in the database for practical reasons. In order to check the identities of reference strains, comparative $16 \mathrm{~S}$ rDNA sequence analysis was carried out for more than half of the reference strains.

\section{METHODS}

Strains. A total of 730 strains from international culture collections, commercial starter culture companies and other laboratories provided the reference material. Strains with questionable classification were identified by comparative $16 \mathrm{~S}$ rDNA sequence analysis. The reference strains represent 220 species out of 46 genera from the two suborders Micrococcineae and Corynebacterineae (Actinomycetales, Actinobacteria) as well as morphologically similar genera see the list of coryneform and related or morphologically similar species contained in the FT-IR spectral identification database in IJSEM Online (http://ijs.sgmjournals.org).

Sample preparation. Sample preparation was performed according to the methods of Kümmerle et al. (1998). The cells were incubated at $30{ }^{\circ} \mathrm{C}$ for $24 \mathrm{~h}$ (tryptone soya agar, containing $15.0 \mathrm{~g}$ tryptone, $5.0 \mathrm{~g}$ soya peptone, $5.0 \mathrm{~g}$ sodium chloride and $15.0 \mathrm{~g}$ agar per litre; Oxoid). Few strains yielding a clumpy suspension were subjected to ultrasonication for $2 \times 10$ s at $25 \%$ power with a Bandelin Sonopuls HD2200, probe MS72 (Bandelin Electronic) in order to improve spectral quality.

FT-IR spectroscopy. All spectra were recorded and evaluated according to the methods of Kümmerle et al. (1998) using an IFS-28B FT-IR spectrometer (Bruker). To diminish the difficulties arising from unavoidable baseline shifts and to improve the resolution of complex bands, the first derivation of the digitized original spectrum was used.

The adjustment of FT-IR parameters such as selection of relevant spectral frequency ranges, their weighting and socalled reproducibility levels was done based on Bruker (1996) and Kümmerle et al. (1998) but was extended in this work. In order to calibrate the spectral distance values obtained in the identification hit lists, the reproducibility levels were determined for each of the five relevant frequency ranges (spectral windows) W1 (3000-2800 $\left.\mathrm{cm}^{-1}\right)$, W2 (1800$\left.1500 \mathrm{~cm}^{-1}\right)$, W3 (1500-1200 $\left.\mathrm{cm}^{-1}\right)$, W4 (1200-900 $\left.\mathrm{cm}^{-1}\right)$ and W5 $\left(900-700 \mathrm{~cm}^{-1}\right)$. For this procedure, eight species were used which were represented by between five and 42 strains each. The reproducibility levels normalize the different spectral reproducibility variation encountered in each frequency range. Their adjustment allows the threshold value for a valid identification of an isolate at the species level to be set at a spectral distance of $1 \cdot 0-1 \cdot 5$, approximately. This implies that if the spectral distance between an isolate and the first hit of the identification hit list is higher than $1 \cdot 5$, the isolate cannot be identified. The reproducibility levels differ greatly between different frequency ranges, corresponding to the different degree of spectrum variation within the spectral windows. The subsequent selection of spectral windows and their weighting was done according to the results from the internal validation. 
Comparative 16S rDNA sequence analysis. A total of 352 reference strains of questionable identity were subjected to comparative $16 \mathrm{~S}$ rDNA sequence analysis. The strains were lysed and an amplification PCR of the almost complete 16S rDNA molecule was performed according to the methods of von Stetten et al. (1998). Two universal 16S rDNA-binding primers were used for the amplification PCR: 5'f (5'AGAGTTTGATCCTGGCTCA-3'; positions 8-26 in the Escherichia coli numbering system, Brosius et al., 1978) and 3'r (5'-CGGCTACCTTGTTACGAC-3'; E. coli numbering 1511-1493). The PCR protocol started with a denaturation step for $5 \mathrm{~min}$ at $95^{\circ} \mathrm{C}$, followed by 30 cycles of denaturation for $20 \mathrm{~s}$ at $95^{\circ} \mathrm{C}$, primer annealing for $40 \mathrm{~s}$ at $55^{\circ} \mathrm{C}$ and elongation for $2 \mathrm{~min}$ at $72^{\circ} \mathrm{C}$ each. A final elongation step was added at $72{ }^{\circ} \mathrm{C}$ for $5 \mathrm{~min}$. After PCR amplification, the DNA was purified using the QIAquick PCR purification kit (Qiagen) according to the instructions of the manufacturer, followed by a PEG precipitation of the purified product according to the methods of Facius et al. (1999). After purification, the samples were subjected to a cycle-sequencing PCR according to the methods of Facius et al. (1999), using the ThermoSequenase fluorescent labelled primer cycle-sequencing kit with 7-deaza-dGTP (Amersham Pharmacia Biotech). DMSO (11\%,v/v) and formamide $(7 \%, v / v)$ were added to facilitate the cycle-sequencing PCR. Fluorescently labelled primers 5'f, 3'r, 699R [5'GGGTTG(AGT)GCTCGTT-3'; E. coli numbering 1114$1100]$ or $609 \mathrm{~V}$ [5'-TTAGATACCCT(AG)GTAGT-3'; $E$. coli numbering 788-804] were used for the cycle-sequencing PCR (primers 699R and 609V: Ludwig \& Strunk, http:// www.biol.chemie.tu-muenchen.de/pub/ARB/documentation/ARB.ps). Independently of the primer applied, the protocol for the cycle-sequencing PCR started with a first denaturation step for $5 \mathrm{~min}$ at $88^{\circ} \mathrm{C}$, followed by 25 cycles of denaturation for $30 \mathrm{~s}$ at $88^{\circ} \mathrm{C}, 25 \mathrm{~s}$ at the primer specific annealing temperature and elongation for $3 \mathrm{~min}$ at $50^{\circ} \mathrm{C}$. A final elongation step at $50^{\circ} \mathrm{C}$ for $5 \mathrm{~min}$ was added. Annealing temperatures for the different cycle sequencing primers used were as follows: $42^{\circ} \mathrm{C}$ for $5^{\prime} \mathrm{f}, 45^{\circ} \mathrm{C}$ for $3^{\prime} \mathrm{r}, 37^{\circ} \mathrm{C}$ for $699 \mathrm{R}$ and $35^{\circ} \mathrm{C}$ for $609 \mathrm{~V}$. Sequencing was performed on a LI-COR sequencer (MWG Biotech), typically yielding sequence lengths of approximately 800-1000 bases per run.

Identification of the strains was accomplished by comparison of the partial sequences with sequences from databases such as GenBank (Altschul et al., 1997), the RDP database (Maidak et al., 2000) and the ARB database (Ludwig \& Strunk, see above). According to Stackebrandt \& Goebel (1994), a similarity of more than $97 \%$ strongly points to species identity between query sequence and retrieved database sequences, although there are exceptions to this rule (e.g. Fox et al., 1992; Lechner et al., 1998). Identification of a sequence in the ARB software environment was accomplished by addition of the aligned query sequence into a validated and optimized tree based on aligned 16S rDNA sequences by maximum-parsimony analysis while keeping its topology constant (Ludwig et al., 1998).

Internal validation. Performing an internal validation means that newly recorded single spectra from strains already available in the spectral library are tested against the database. Randomly selected single spectra of 208 strains from 208 species out of 41 genera provided the test set for this internal validation, representing a cross-section of the coryneform bacteria and related organisms. The reference set consisted of average spectra of the complete spectral library of 730 strains. The average spectra from the 208 test strains were included in the reference set which did not comprise the single spectra of the test set. The test set spectra were then identified by the reference set and the result was determined at the strain, species and genus level by evaluating the relationship between the test spectrum and the first hit in the identification hit list. The result was counted as a correct identification at the strain level if the test spectrum was identified with a spectral distance value $D<1.5$ by its corresponding average spectrum. In case of an identification of the test spectrum by an average spectrum of a strain belonging to the same species, the result corresponded to a correct identification at the species level. Finally, if at least the genus matched, the result was counted as a correct identification at the genus level. The results of identification of all test spectra were averaged to obtain the so-called percentage correctness of identification. This parameter was determined for each frequency range W1-W5 separately and subsequently also for combinations of the five ranges altogether or only spectral windows W2-W5. The quality of identification obtained for each frequency range separately specified their eventual weighting. For comparison, the correctness of identification was also determined for the parameters used for the identification of yeasts by FT-IR spectroscopy by Kümmerle et al. (1998).

Simulated external validation. In this case, in contrast to an internal validation, the strains tested against the database are not comprised in the spectral library. A total of 544 strains from 54 species with at least three strains per species from 16 genera were used for this quasi-external validation for proof of principle. The average spectrum of one strain was excluded from the spectral library and this strain was then tested against the remaining database. If the first hit belonged to an average spectrum of a strain from the same species and the spectral distance value $D$ was below $1 \cdot 5$, the result was counted as a correct identification at the species level. If the identification corresponded to a different species from the same genus, the result represented a correct identification at the genus level. In case of a spectral distance value $D>1 \cdot 5$, the strain was counted as not-identified. A misidentification was noted if a strain was identified incorrectly. The results of the identification of all test strains belonging to the same species was averaged to obtain the mean correctness of identification for each species considered.

\section{RESULTS AND DISCUSSION}

\section{Composition of the identification database}

The established database consists of IR average spectra from 730 reference strains belonging to 220 different coryneform species and phylogenetically or morphologically related taxa out of 46 genera, 40 of them from the two suborders Micrococcineae and Corynebacterineae (Actinomycetales, Actinobacteria) (see the list in IJSEM Online). A total of 192 species $(87 \%)$ are represented by type strains. Each average spectrum was calculated from at least three matching single spectra.

Several genera were not included in the database since they did not allow cultivation under the required culture conditions. These are the single-species genera Frigoribacterium (Kämpfer et al., 2000), Cryobacterium (Suzuki et al., 1997) and Renibacterium (Sanders 
\& Fryer, 1980) due to their obligate psychrophily. Furthermore, the genus Bogoriella (Groth et al., 1997) and the genus Rarobacter (Yamamoto et al., 1988) were excluded for obligate alkaliphily and for requirement of catalase, haemoglobin or haemin for growth in air, respectively. The genera Tetrasphaera (Maszenan et al., 2000) and Mycobacterium Lehmann and Neumann 1896 are not represented due to their extremely slowly growing species.

On the other hand, strains from morphologically similar genera such as Staphylococcus were included to enable safe identification results of Gram-positive cocci independent of their $\mathrm{G}+\mathrm{C}$ content, in particular, since staphylococci are widely distributed in the environment and have frequently been isolated from cheeses (Bockelmann et al., 1997; Irlinger et al., 1997; Carnio et al., 2000).

Not considering species from the above-mentioned excluded genera, there are approximately 210 species from the two suborders Micrococcineae and Corynebacterineae validly described so far and this number is growing continuously. A total of 180 of these species are included in the database, which corresponds to a coryneform coverage of $85 \%$.

\section{Comparative 16S rDNA sequence analysis}

After having included several hundred strains in the database, it became apparent from FT-IR cluster analyses that, sometimes, strains carrying completely different species and/or genus names grouped together at a very high level of spectral similarity. In order to check the identity of these questionable strains, comparative 16S rDNA sequence analysis was carried out for 352 strains. Partial sequences of typical sequence lengths between 800 and 1000 nucleotides were determined and identified using GenBank's BLAST, the RDP and the ARB databases. Generally, there was good agreement between the results obtained from the hit lists of GenBank and the RDP database. As a result, $224(64 \%)$ of these strains were reclassified according to the sequence analysis while the other 128 strains $(36 \%)$ proved to be correctly classified. Fig. 1(a) shows an example for a number of strains clustering at a very high level of spectral similarity while carrying many different genus and species denotations, some of which have never been validly described (names within quotation marks). After comparative 16S rDNA sequence analysis, each of these strains was identified as Rhodococcus erythropolis (Fig. 1b). Comparative sequence analysis and, if necessary, strain reclassification was carried out in order to calibrate the spectral library for subsequent determination of its quality of identification.

According to Stackebrandt \& Goebel (1994), homologies of more than $97 \%$ strongly point to species identity between query sequence and database sequences, although exceptions to this rule have been reported (e.g. Fox et al., 1992). However, a more

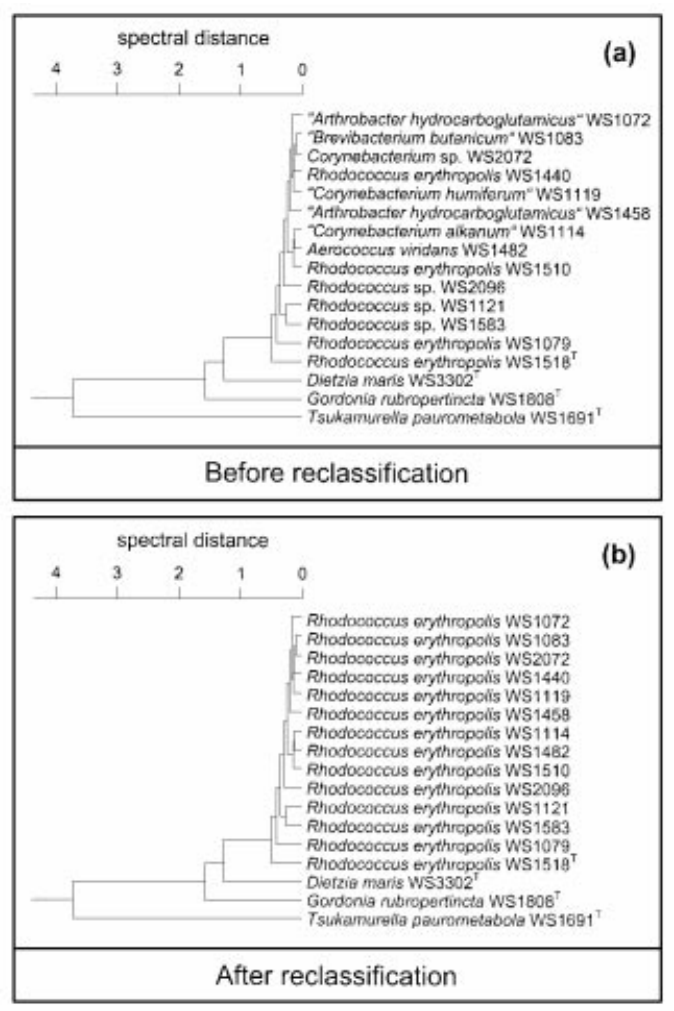

Fig. 1. Dendrogram of spectrometrically similar reference strains. Average linkage, correlation with normalized to reproducibility level. Frequency ranges with weights and reproducibility levels: $3000-2800 \mathrm{~cm}^{-1} / 0 \cdot 8 / 3 \cdot 3 ; 1800-1500 \mathrm{~cm}^{-1} / 0 \cdot 8 / 5$; $1500-1200 \mathrm{~cm}^{-1} / 0 \cdot 9 / 20 ; 1200-900 \mathrm{~cm}^{-1} / 0 \cdot 9 / 33 ; 900-700 \mathrm{~cm}^{-1} / 0.9 /$ 116. Unweighted pair group method algorithm (UPGMA). (a) Classification of reference strains before comparative 16S rDNA sequence analysis. (b) Partial reclassification after sequence analysis.

thorough characterization of the strains including DNA-DNA hybridization and determination of physiological and biochemical properties was not possible due to the vast number of strains dealt with. For this reason, further efforts to differentiate strains reclassified as Arthrobacter ramosus/Arthrobacter pascens or Staphylococcus vitulinus/Staphylococcus pulvereri which are indistinguishable by means of comparative 16S rDNA analysis have not been undertaken (see the list in IJSEM Online).

The need to carefully check the identities of reference strains on a regular basis has also been noted by Felske et al. (1999) in the course of assessing the heterogeneity of partial 16S rRNA sequences of coryneform strains by TGGE. These authors explained the aberrant behaviour of some strains by the so-called 'human factor', which refers to the handling of strains in laboratories over long periods of time. Moreover, coryneform bacteria have often been misclassified in the past (Altenburger et al., 1997). Kollöffel et al. (1997) have also reported irregularities after investigating reference strains. 


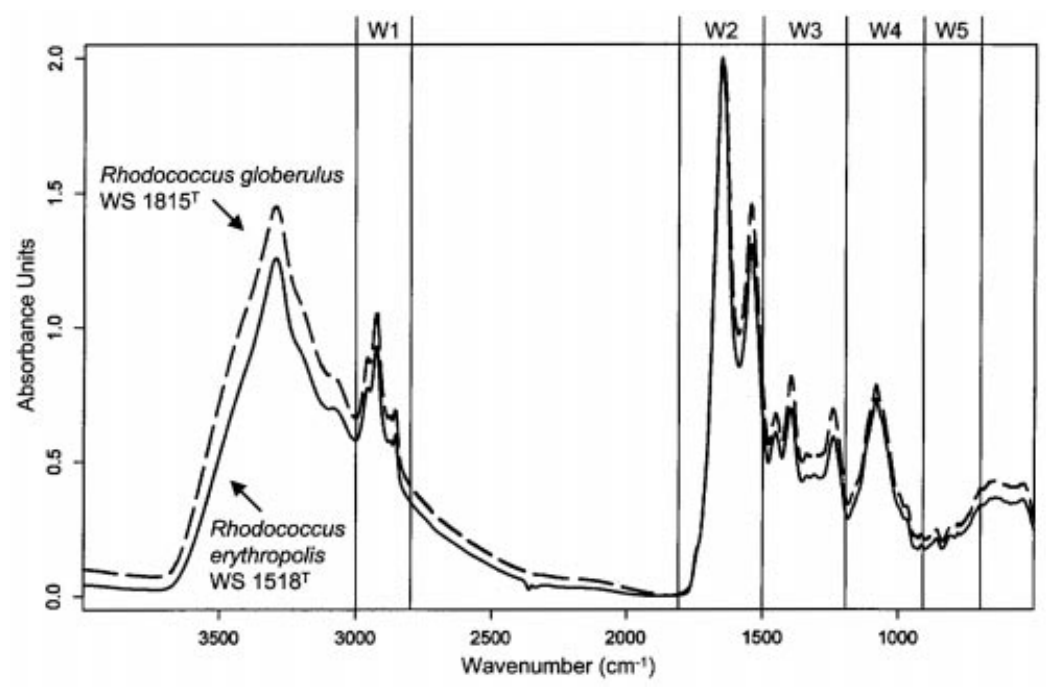

Fig. 2. Normalized averaged absorbance spectra of the type strains from two example species and frequency ranges W1-W5.

\section{Internal validation}

After the determination of the so-called reproducibility levels obtained for each spectral window, the different frequency ranges' capacity for correct identification was determined by running identifications of a spectra test set against the complete database separately for each of the five spectral windows. The overall correctness of identification obtained for each frequency range (data not shown) was used for a permutation of different spectral window combinations in order to obtain those yielding highest values for correct identification. The combination comprising all five spectral windows was found to be optimal. In this internal validation, $93 \cdot 9,98 \cdot 1$ and $99 \cdot 5 \%$ of the 208 test strains were correctly identified at the strain, species and genus level, respectively. These values are optimized, meaning that when in four cases a single spectrum was not correctly identified by its corresponding average spectrum, several further single spectra were recorded and included to form a new average spectrum in order to increase the representation of the spectral variety of the same strain in the database. The parameters found to be optimal for the identification of coryneform bacteria by FT-IR spectroscopy are listed in the legend for Fig. 1. Fig. 2 displays the normalized averaged IR spectra of the type strains from two example species together with the five relevant frequency ranges.

In contrast, performing this internal validation with the same strain set but using instead the optimized parameters of the spectral database for yeasts as described by Kümmerle et al. (1998) resulted in mean values for correct identification at strain, species and genus level of $90.6,94.3$ and $96.7 \%$, respectively. The comparison between 'yeast parameters' and 'coryneform parameters' clearly shows that it is worthwhile determining the optimal settings for each group of organisms separately and that adjustments proven to be optimal for one group do not necessarily represent the optimum for another group (see also Helm et al., 1991).

\section{Simulated external validation}

The quality of the database was further assessed by carrying out a simulated external validation. One strain was singled out and the library was built up without the average spectrum of this strain. Subsequently, the strain was identified by the spectral library and the correct identification was checked at the species and genus level. A total of 544 strains from 54 species containing a minimum number of three strains per species were used. As a result, $87.3 \%$ of the strains were correctly identified at the species level and $95.4 \%$ at the genus level; $12.7 \%$ did not result in a correct identification at the species level, $1.3 \%$ of which were not identified while $11.4 \%$ were misidentified.

While some species yield $100 \%$ correctness of identification even if being represented only by a low number of strains per species, the general trend shows a correlation between the number of strains per species in the library and the percentage of correct identification obtained (Fig. 3, shading added for illustration reasons only). Roughly, the more strains a species is represented by in the identification database, the more likely is a correct identification at the species level. Likewise, the probability of a misidentification decreases with an increasing number of strains (data not shown). This observation can be explained with an increased coverage of the intraspecies variety in case of a high number of strains per species. The number of non-identified strains, i.e. spectra that were identified with a spectral distance $D>1 \cdot 5$, equals zero for most of the species under investigation. Seven species out of 


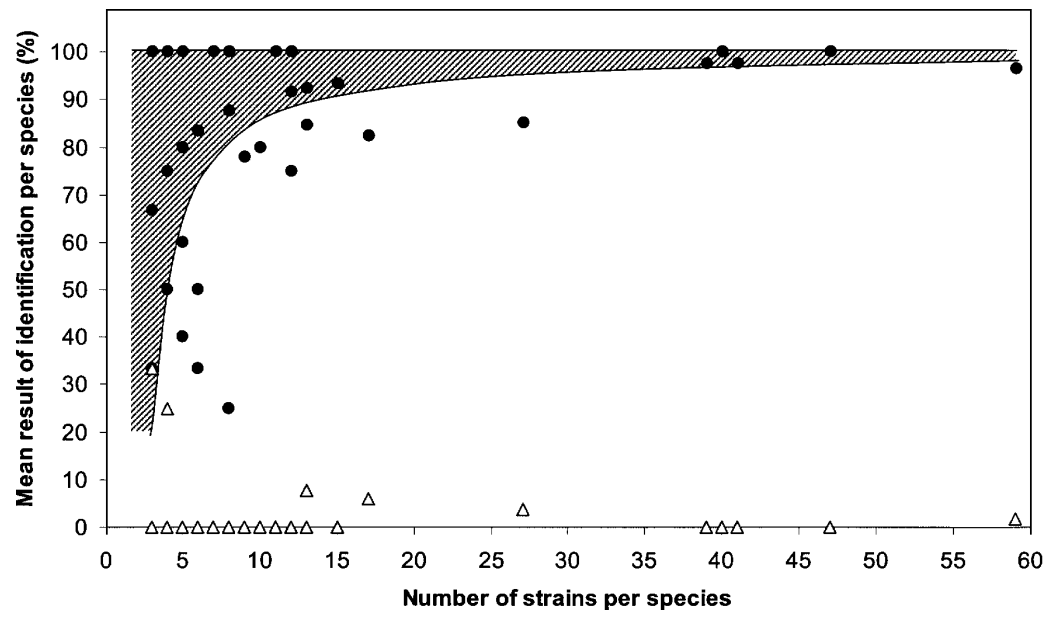

Fig. 3. External validation using 544 strains belonging to 54 species from 16 genera. One datapoint displays the mean result of identification over all strains per considered species vs number of strains per species in the spectral library. $\bullet$, Correct identification at the species level; $\triangle$, non-identified (spectral distance $D>1 \cdot 5$ ). Shading added for illustration reasons only.

54, however, contained strains that could not be identified. This indicates that the variability range of some species is better represented in the reference library than that of others, independent of the number of strains available in the spectral database. In order to allow the identification of future isolates which might show a higher spectral similarity to these outlier strains than to the other 'core' strains of a particular species, it is sensible to retain the non-identified strains in the database. These isolates' subsequent addition as reference spectra contributes to a better representation of the corresponding species' diversity in the library.

\section{Evaluation of identification quality by comparison of results with those described in the literature}

Several publications report on the identification capacity of various methods dealing with different groups of micro-organisms (Table 1). The identification of coryneform bacteria and related genera has been evaluated by using the BIOLOG Identification System (Biolog), API Coryne database (bioMérieux) and the RapID CB Plus system (Remel), three commercially available identification kits based on the analysis of physiological properties. The latter two identification databases contain only a limited number of species, most of which are clinically relevant coryneform bacteria. The percentage values of correct identification achieved in external validations differ greatly between these systems, yielding best results for the API Coryne database (Table 1).

Several studies have analysed the capacity for identification of micro-organisms by FT-IR spectroscopy. Most studies have only performed internal validations where the percentage of correct identification is generally higher than in the case of an external validation. Moreover, the size of the spectral libraries under investigation has been rather limited except for the databases reported by Kümmerle et al. (1998) and by this study.

When comparing published identification results, it is therefore necessary to compare the size and composition of the databases evaluated as well as the size and composition of the set of test organisms used for validation. Moreover, the kind of validation performed (internal vs external) must be noted carefully since the results of correct identification will largely be influenced by the presence or absence of the tested strains in the library. The effects of the composition and size of both database and test set on the identification quality on the one hand is hardly separable from the effect of the kind of validation performed on the other hand with the limited data available. Generally, an internal validation performed with a small heterogeneous database (i.e. only few strains per genus and genera from different phyla) (Table 1; Helm et al., 1991) will yield much higher values for correct identification than an external validation performed on a rather homogeneous database (i.e. closely related taxa) due to a higher percentage of misidentified strains in the latter (e.g. Funke et al., 1998). Misidentification occurs if a test strain is less similar to other strains of its own species than to a strain of a different species.

Results are also influenced by the intrataxa separation of the particular group of organisms studied: in case of comparable heterogeneity of databases and similar heterogeneity of the test sets (i.e. numbers of strains per species or genus in the same order of magnitude), a highly different result of correct species allocation in an external validation points to a different intrataxa separability between the organisms analysed, e.g. between yeasts and coryneform bacteria (Kümmerle et al., 1998 vs this study). Our results seem to indicate that yeast taxa can be considered more distinctive than 
Table 1. Literature survey: identification capacity of various methods used for identifying different groups of micro-organisms

Abbreviations: st, strain(s); sp, species; gen, genus/genera; lev, level; non-id, non-identified (FT-IR spectral distance $D>1 \cdot 5$ ); misid, misidentified at the species level.

\begin{tabular}{|c|c|c|c|c|c|c|}
\hline Method & Organisms studied & $\begin{array}{l}\text { Composition of } \\
\text { identification database } \\
\text { (average distribution } \\
\text { of st/sp and st/gen) }\end{array}$ & $\begin{array}{l}\text { Validation } \\
\text { performed }\end{array}$ & $\begin{array}{l}\text { Composition of } \\
\text { test organisms } \\
\text { for validation }\end{array}$ & Result of validation & Reference \\
\hline $\begin{array}{l}\text { BIOLOG Identification } \\
\text { System } 3.50 \text { (BIOLOG) }\end{array}$ & $\begin{array}{l}\text { Asporogenous, aerobic Gram- } \\
\text { positive rods }\end{array}$ & $\begin{array}{l}\text { Approx. } 250 \mathrm{sp}, 35 \text { genera }(7 \cdot 1 \mathrm{sp} / \mathrm{gen}) \\
96 \mathrm{sp} \text { and } 21 \text { gen of which are high- } \\
\mathrm{G}+\mathrm{C} \text { Gram-positive bacteria }(4 \cdot 6 \mathrm{sp} / \mathrm{gen})\end{array}$ & External & $\begin{array}{l}174 \mathrm{st}, 42 \mathrm{sp}, 12 \text { gen }(4 \cdot 2 \mathrm{st} / \mathrm{sp}, \\
14 \cdot 5 \mathrm{st} / \mathrm{gen})\end{array}$ & $\begin{array}{l}34 \% \text { correct at sp lev, } 7 \% \text { non-id, } \\
58 \% \text { misid }\end{array}$ & $\begin{array}{l}\text { Lindenmann et al. (1995); Biolog } \\
\text { (2000) }\end{array}$ \\
\hline $\begin{array}{l}\text { API Coryne database } 2.0 \\
\text { (bioMérieux) }\end{array}$ & $\begin{array}{l}\text { Clinically relevant coryneform } \\
\text { bacteria and related taxa as well } \\
\text { as Listeria spp. }\end{array}$ & $\begin{array}{l}\text { Approx. } 48 \mathrm{sp}, 15 \text { genera }(3 \cdot 2 \mathrm{sp} / \text { gen }) \\
44 \mathrm{sp} \text { and } 13 \text { gen of which are high- } \\
\text { G+C Gram-positive bacteria }(3 \cdot 4 \mathrm{sp} / \text { gen })\end{array}$ & External & $\begin{array}{l}407 \mathrm{st}, 54 \mathrm{sp}, 20 \text { gen }(8 \mathrm{st} / \mathrm{sp} \text {, } \\
20 \mathrm{st} / \mathrm{gen})\end{array}$ & $\begin{array}{l}90.5 \% \text { correct at sp lev, } 5.6 \% \text { non- } \\
\text { id, } 3.8 \% \text { misid }\end{array}$ & $\begin{array}{l}\text { Funke } e t \text { al. (1997b); bioMérieux } \\
\text { (2000) }\end{array}$ \\
\hline $\begin{array}{l}\text { RapID CB Plus system } \\
\text { (Remel) }\end{array}$ & $\begin{array}{l}\text { Clinically relevant coryneform } \\
\text { bacteria and related taxa as well } \\
\text { as Listeria spp. }\end{array}$ & $\begin{array}{l}\text { Approx. } 52 \mathrm{sp}, 14 \text { genera }(3 \cdot 7 \mathrm{sp} / \mathrm{gen}) \\
44 \mathrm{sp} \text { and } 12 \text { gen of which are high- } \\
\text { G+C Gram-positive bacteria }(3 \cdot 7 \mathrm{sp} / \text { gen })\end{array}$ & External & $\begin{array}{l}378 \mathrm{st}, 49 \mathrm{sp}, 16 \text { gen }(8 \mathrm{st} / \mathrm{sp}, \\
23 \mathrm{st} / \mathrm{gen})\end{array}$ & $\begin{array}{l}80.9 \% \text { correct at sp lev, } 3.2 \% \text { non- } \\
\text { id, } 15.7 \% \text { misid }\end{array}$ & Funke $e t$ al. (1998); Remel (2000) \\
\hline FT-IR & Actinomycetes & $46 \mathrm{st}, 41 \mathrm{sp}, 14 \mathrm{gen}(1 \cdot 1 \mathrm{st} / \mathrm{sp}, 3 \cdot 3 \mathrm{st} / \mathrm{gen})$ & Internal & 39 st from identification database & $\begin{array}{l}89 \% \text { correct at st lev, no further } \\
\text { information provided }\end{array}$ & Haag et al. (1996) \\
\hline FT-IR & $\begin{array}{l}\text { Low-G+C Gram-positive bacteria } \\
\text { (Staphylococcus spp., Clostridium } \\
\text { spp., Streptococcus spp.), } \\
\gamma \text {-Proteobacteria (Aeromonas spp., } \\
\text { Pseudomonas spp. and } \\
\text { Enterobacteriaceae) }\end{array}$ & $97 \mathrm{st}, 42 \mathrm{sp}, 17$ gen $(2 \cdot 3 \mathrm{st} / \mathrm{sp}, 5 \cdot 7 \mathrm{st} / \mathrm{gen})$ & Internal & 72 st from identification database & $\begin{array}{l}83.3 \% \text { correct at st lev, } 94 \cdot 4 \% \\
\text { correct at sp lev, } 97 \cdot 2 \% \text { correct at } \\
\text { gen lev }\end{array}$ & Helm et al. (1991) \\
\hline FT-IR & Yeasts & $332 \mathrm{st}, 74 \mathrm{sp}, 18$ gen $(4.5 \mathrm{st} / \mathrm{sp}, 18 \mathrm{st} / \mathrm{gen})$ & External & $\begin{array}{l}717 \text { st, } 36 \mathrm{sp}, 11 \text { gen }(20 \mathrm{st} / \mathrm{sp}, \\
65 \mathrm{st} / \mathrm{gen})\end{array}$ & $\begin{array}{l}97.5 \% \text { correct at sp lev, } 0.8 \% \text { non- } \\
\text { id, } 1.7 \% \text { tentatively identified }\end{array}$ & Kümmerle et al. (1998) \\
\hline \multirow[t]{2}{*}{ FT-IR } & $\begin{array}{l}\text { Coryneform bacteria and } \\
\text { phylogenetically or morphologically } \\
\text { related genera }\end{array}$ & $730 \mathrm{st}, 220 \mathrm{sp}, 46$ gen $(3 \cdot 3 \mathrm{st} / \mathrm{sp}, 16 \mathrm{st} / \mathrm{gen})$ & Internal & $\begin{array}{l}208 \mathrm{st}, 208 \mathrm{sp}, 41 \mathrm{gen} \text { from } \\
\text { identification database }(1 \cdot 0 \mathrm{st} / \mathrm{sp} \text {, } \\
5 \cdot 1 \mathrm{st} / \mathrm{gen})\end{array}$ & $\begin{array}{l}93.9 \% \text { correct at st lev, } 98 \cdot 1 \% \\
\text { correct at sp lev, } 99.5 \% \text { correct at } \\
\text { gen lev }\end{array}$ & This study \\
\hline & & & External & $\begin{array}{l}544 \mathrm{st}, 54 \mathrm{sp}, 16 \text { gen }(10 \mathrm{st} / \mathrm{sp} \text {, } \\
34 \mathrm{st} / \mathrm{gen}\end{array}$ & $\begin{array}{l}87.3 \% \text { correct at sp lev, } 95 \cdot 4 \% \\
\text { correct at gen lev, } 1.3 \% \text { non-id, } \\
11 \cdot 4 \% \text { misid }\end{array}$ & \\
\hline
\end{tabular}


coryneform taxa since the percentage of misidentified isolates was found to be much lower. It appears that, in contrast to yeast taxa, coryneform taxa seem to be rather contiguous, exhibiting a certain amount of overlap of different taxonomical characteristics. Taxa merging into each other lacking rather discrete boundaries at the species or genus level will easily be confused, resulting in high percentages of misidentified isolates. This hypothesis, drawn from comparison between identification results of two phylogenetically well-separated kinds of micro-organisms by the same technique (FT-IR spectroscopy), is further supported by the observation that a high percentage of misidentification has also been noted for the identification of coryneform bacteria by physiological properties (cf. Table 1). Reference to the literature reveals that even though a wide spectrum of chemotaxonomical differentiation methods have been applied to the classification of actinobacterial taxa, differentiation down to the species level could not be achieved satisfactorily in all cases, sometimes not even to the genus level. Each of these techniques allows differentiation between some taxa while they fail to separate others (Kämpfer \& Kroppenstedt, 1996; Altenburger et al., 1997; Busse \& Schumann, 1999; Felske et al., 1999). Stackebrandt et al. (1997) have noted that the rich chemical, morphological and physiological diversity of phylogenetically closely related genera makes the description of families and higher taxa so broad that they become meaningless for the description of the enclosed taxa. Most main actinobacterial lines of descent, described as orders, suborders and families, are not well separated and the statistical significance of branching points is low. Because of the lack of common properties of phylogenetic significance shared by most taxa of a higher taxon, their delineation from each other is somewhat arbitrary and artificial (Stackebrandt \& Schumann, 2000). Therefore, even though actinobacterial taxa form a systematically well-derivable group, due to their overlapping (or even contradictory) distribution of taxonomical characters, the possibilities for their differentiation by non-genotypical methods remain somewhat limited.

Examples for a certain degree of interference between different taxonomical characteristics and, as a result, diverging taxonomical opinions can be taken from the on-going discussion as to the separation or unification of different genera such as Microbacterium/Aureobacterium (Rainey et al., 1994; Takeuchi \& Hatano, 1998), Cellulomonas/Oerskovia (Stackebrandt et al., 1982; Stackebrandt \& Prauser, 1994) or Corynebacterium/Turicella (Funke et al., 1994; Pascual et al., 1995; Ruimy et al., 1995). These genera are or appear to be phylogenetically intermixed but can be differentiated by means of other taxonomic properties.

Taxonomically overlapping reference species are likely to result in an FT-IR hit list confusion and misidentification of test strains. Thus, an extensive representation of intraspecies and intragenus variety by a substantial number of reference strains is indeed critical for a high percentage value of correct species identification, but will not decrease confusion within a highly contiguous group of organisms. On the other hand, with regard to the behaviour of a single strain, e.g. in epidemiological analyses, a good coverage of intraspecies variety by a large number of reference strains will decrease the probability for differentiation of this particular strain from the others (i.e. yield low values of correct identification at the strain level in general), especially if the strains are very similar, but will yield high values of correct species identification. From the data presented in Fig. 3, we expect that, on average, approximately five to ten different strains per species in a coryneform FT-IR database are appropriate in order to achieve a reasonable identification capacity, depending on the spectral variability within the species. A considerable advantage of working with an FT-IR spectral library for identification is the users' possibility to influence the size and composition of the database themselves, i.e. by continuously adding strains in order to keep the reference library up-to-date or to include own sets of micro-organisms.

\section{CONCLUSION}

The FT-IR spectral database is a valuable tool for the rapid, simple and cost-efficient identification of coryneform strains from a variety of sources. Comparison of identification results reported in the literature showed that an overall correct identification of more than $95 \%$ at the species level has not been achieved by any nongenetical method so far. Therefore, our results again confirm that coryneform bacteria are a group of organisms whose taxa are not well separated by phenotypical characteristics and, therefore, are difficult to be identified properly. The identification values obtained in this work are well within the range of those having been reported in the literature for identification of these high-G $+\mathrm{C}$ Gram-positive bacteria. In order to obtain an identification at the species level with a reasonable probability, each species should be represented by an approximate number of five to ten strains in the database. For improvement of the library's capability for correct identification of coryneform isolates, the number of strains should be increased constantly both for intraspecific representation and for coverage of relevant taxa in general.

\section{ACKNOWLEDGEMENTS}

The authors wish to thank Wolfgang Ludwig for providing the ARB software environment together with the ARB 16S rDNA database and for giving valuable information whenever necessary. We are grateful to Lyudmila Evtushenko (VKM, Russia), Ingrid Groth (Hans-Knöll-Institut für Naturstoff-Forschung e.V., Jena, Germany), Klaus P. Schaal (Rheinische Friedrich-Wilhelms-Universität, Bonn, Germany) and Karin Schubert (Ludwig Maximilians Universität, Munich, Germany) for supplying us with strains from their collections and to the companies Chr. Hansen $\mathrm{GmbH}$, Rhodia GmbH, SKW Biosystems $\mathrm{GmbH}$ and Wisby GmbH \& Co. KG (all Germany) for supplying us 
with starter culture strains. Thanks are due to Joachim Charzinski for helping us with the LINUX operating system. The technical assistance of Sven Illgner, Patrizia Hägele and Louise Arnold is greatly appreciated. Special thanks are due to Cornelia Fischer for excellent technical assistance. This work was supported by the FEI (Forschungskreis der Ernährungsindustrie e.V., Bonn), the AiF (Arbeitskreis für industrielle Forschung) and the Ministry of Economics and Technology, project no. $11627 \mathrm{~N}$.

\section{REFERENCES}

Altenburger, P., Kämpfer, P., Akimov, V. N., Lubitz, W. \& Busse, H.-J. (1997). Polyamine distribution in actinomycetes with group B peptidoglycan and species of the genera Brevibacterium, Corynebacterium, and Tsukamurella. Int J Syst Bacteriol 47, 270-277.

Altschul, S. F., Madden, T. L., Schäffer, A. A., Zhang, J., Zhang, Z., Miller, W. \& Lipman, D. J. (1997). Gapped BLAST and PSI-BLAST: a new generation of protein database search programs. Nucleic Acids Res 25, 3389-3402.

Biolog (2000). Biolog GP Data Base. Release 3.50. Hayward, CA: Biolog.

bioMérieux (2000). API Coryne database 2.0. Marcy-1'Étoile: bioMérieux.

Bockelmann, W., Krusch, U., Engel, G., Klijn, N., Smit, G. \& Heller, K. J. (1997). The microflora of Tilsit cheese. Part 1. Variability of the smear flora. Nahrung 41, 208-212.

Brosius, J., Palmer, M. L., Kennedy, P. J. \& Noller, H. F. (1978). Complete nucleotide sequence of a $16 \mathrm{~S}$ ribosomal RNA gene from Escherichia coli. Proc Natl Acad Sci U S A 75, 4801-4805.

Bruker (1996). Working with the IFS 28/B-Sample Preparation, Measurement and Evaluation of the FT-IR Spectra of Microorganisms, Version 2.2. Ettlingen: Bruker.

Busse, H.-J. \& Schumann, P. (1999). Polyamine profiles within genera of the class Actinobacteria with LL-diaminopimelic acid in the peptidoglycan. Int J Syst Bacteriol 49, 179-184.

Carnio, M. C., Eppert, I. \& Scherer, S. (1999). Analysis of the bacterial surface flora of German and French smeared cheeses with respect to their anti-listerial potential. Int J Food Microbiol 47, 89-97.

Carnio, M. C., Höltzel, A., Rudolf, M., Henle, T., Jung, G. \& Scherer, S. (2000). The macrocyclic peptide antibiotic Micrococcin P1 is secreted by the food-borne bacterium Staphylococcus equorum WS 2733 and inhibits Listeria monocytogenes on soft cheese. Appl Environ Microbiol 66, 2378-2384.

Crocker, F. H., Fredrickson, J. K., White, D. C., Ringelberg, D. B. \& Balkwill, D. L. (2000). Phylogenetic and physiological diversity of Arthrobacter strains isolated from unconsolidated subsurface sediments. Microbiology 146, 1295-1310.

Facius, D., Fartmann, B., Huber, J., Nikoleit, K., Schondelmaier, J. \& Steinhauser, S. (1999). Sequencing Brochure. Instructions for $D N A$ template preparation, primer design and sequencing with the LI-COR DNA Sequencer 4000 and 4200 series, Version 4. Ebersberg: MWG-BIOTECH.

Felske, A., Vancanneyt, M., Kersters, K. \& Akkermans, A. D. L. (1999). Application of temperature-gradient gel electrophoresis in taxonomy of coryneform bacteria. Int J Syst Bacteriol 49, $113-121$

Fox, G. E., Wisotzkey, J. D. \& Jurtshuk, P., Jr (1992). How close is close: 16S rRNA sequence identity may not be sufficient to guarantee species identity. Int J Syst Bacteriol 42, 166-170.

Funke, G., Stubbs, S., Altwegg, M., Carlotti, A. \& Collins, M. D.
(1994). Turicella otitidis gen. nov., sp. nov., a coryneform bacterium isolated from patients with otitis media. Int $J$ Syst Bacteriol 44, 270-273.

Funke, G., von Graevenitz, A., Clarridge, J. E., III \& Bernard, K. A. (1997a). Clinical microbiology of coryneform bacteria. Clin Microbiol Rev 10, 125-159.

Funke, G., Renaud, F. N., Freney, J. \& Riegel, P. (1997b). Multicenter evaluation of the updated and extended API (RAPID) Coryne database 2.0. J Clin Microbiol 35, 3122-3126. Funke, G., Peters, K. \& Aravena-Roman, M. (1998). Evaluation of the RapID CB Plus system for identification of coryneform bacteria and Listeria spp. J Clin Microbiol 36, 2439-2442.

Goodacre, R., Timmins, É. M., Burton, R., Kaderbhai, N., Woodward, A. M., Kell, D. B. \& Rooney, P. J. (1998). Rapid identification of urinary tract infection bacteria using hyperspectral whole-organism fingerprinting and artificial neural networks. Microbiology 144, 1157-1170.

Groth, I., Schumann, P., Rainey, F. A., Martin, K., Schuetze, B. \& Augsten, K. (1997). Bogoriella caseilytica gen. nov., sp. nov., a new alkaliphilic actinomycete from a soda lake in Africa. Int $J$ Syst Bacteriol 47, 788-794.

Haag, H., Gremlich, H.-U., Bergmann, R. \& Sanglier, J.-J. (1996). Characterization and identification of actinomycetes by FT-IR spectroscopy. J Microbiol Methods 27, 157-163.

Helm, D., Labischinski, H. \& Naumann, D. (1991). Elaboration of a procedure for identification of bacteria using Fouriertransform IR spectral libraries: a stepwise correlation approach. J Microbiol Methods 14, 127-142.

Holt, C., Hirst, D., Sutherland, A. \& MacDonald, F. (1995). Discrimination of species in the genus Listeria by Fourier transform infrared spectroscopy and canonical variate analysis. Appl Environ Microbiol 61, 377-378.

Holt, J. G., Krieg, N. R., Sneath, P. H. A., Staley, J. T. \& Williams, S. T. (editors) (1994). Bergey's Manual of Determinative Bacteriology, 9th edn. Baltimore: Williams \& Wilkins.

Irlinger, F., Morvan, A., El Solh, N. \& Bergere, J. L. (1997). Taxonomic characterization of coagulase-negative staphylococci in ripening flora from traditional French cheeses. Syst Appl Microbiol 20, 319-328.

Junge, K., Gosink, J. J., Hoppe, H.-G. \& Staley, J. T. (1998). Arthrobacter, Brachybacterium and Planococcus isolates identified from antarctic sea ice brine. Description of Planococcus mcmeekinii, sp. nov. Syst Appl Microbiol 21, 306-314.

Kämpfer, P. \& Kroppenstedt, R. M. (1996). Numerical analysis of fatty acid patterns of coryneform bacteria and related taxa. Can $J$ Microbiol 42, 989-1005.

Kämpfer, P., Seiler, H. \& Dott, W. (1993). Numerical classification of coryneform bacteria and related taxa. J Gen Appl Microbiol 39, 135-214.

Kämpfer, P., Rainey, F. A., Andersson, M. A., Nurmiaho Lassila, E.-L., Ulrych, U., Busse, H.-J., Weiss, N., Mikkola, R. \& SalkinojaSalonen, M. (2000). Frigoribacterium faeni gen. nov., sp. nov., a novel psychrophilic genus of the family Microbacteriaceae. Int J Syst Evol Microbiol 50, 355-363.

Klatte, S. (1995). Polyphasische automatisierte Identifizierung der Gattungen Corynebacterium Lehmann \& Neumann 1896 und Rhodococcus Zopf 1891. PhD thesis, University of Osnabrück.

Kollöffel, B., Burri, S., Meile, L. \& Teuber, M. (1997). Development of 16S-rRNA oligonucleotide probes for Brevibacterium, Micrococcus/Arthrobacter and Microbacterium/Aureobacterium used in dairy starter cultures. Syst Appl Microbiol 20, $409-417$. 
Kollöffel, B., Meile, L. \& Teuber, M. (1999). Analysis of brevibacteria on the surface of Gruyere cheese detected by in situ hybridization and by colony hybridization. Lett Appl Microbiol 29, 317-322.

Kümmerle, M., Scherer, S. \& Seiler, H. (1998). Rapid and reliable identification of fermentative yeasts by Fourier-transform infrared spectroscopy. Appl Environ Microbiol 64, 2207-2214.

Lechner, S., Mayr, R., Francis, K. P., Prüß, B. M., Kaplan, T., Wießner-Gunkel, E., Stewart, G. S. A. B. \& Scherer, S. (1998). Bacillus weihenstephanensis sp. nov., is a new psychrotolerant species of the Bacillus cereus group. Int J Syst Bacteriol 48, 1373-1382.

Lednická, D., Mergaert, J., Cnockaert, M. C. \& Swings, J. (2000). Isolation and identification of cellulolytic bacteria involved in the degradation of natural cellulosic fibres. Syst Appl Microbiol 23, 292-299.

Lindenmann, K., von Graevenitz, A. \& Funke, G. (1995). Evaluation of the Biolog system for the identification of asporogenous, aerobic gram-positive rods. Med Microbiol Lett 4, 287-296.

Ludwig, W., Strunk, O., Klugbauer, S., Klugbauer, N., Weizenegger, M., Neumaier, J. \& Bachleitner, M. (1998). Bacterial phylogeny based on comparative sequence analysis. Electrophoresis 19, 554-568.

Maidak, B. L., Cole, J. R., Lilburn, T. G. \& 9 other authors (2000). The RDP (Ribosomal Database Project) continues. Nucleic Acids Res 28, 173-174.

Maszenan, A. M., Seviour, R. J., Patel, B. K. C., Schumann, P., Burghardt, J., Tokiwa, Y. \& Stratton, H. M. (2000). Three isolates of novel polyphosphate-accumulating Gram-positive cocci, obtained from activated sludge, belong to a new genus, Tetrasphaera gen. nov., and description of two new species, Tetrasphaera japonica $\mathrm{sp}$. nov., and Tetrasphaera australiensis sp. nov. Int J Syst Evol Microbiol 50, 593-603.

Naumann, D., Helm, D. \& Schultz, C. (1994). Characterization and identification of micro-organisms by FT-IR spectroscopy and FT-IR microscopy. In Bacterial Diversity and Systematics, pp. 67-85. Edited by F. G. Priest, A. Ramos Cormenzana \& B. J. Tindall. New York: Plenum.

Pascual, C., Lawson, P. A., Farrow, J. A. E., Navarro Gimenez, M. \& Collins, M. D. (1995). Phylogenetic analysis of the genus Corynebacterium based on 16S rRNA gene sequences. Int J Syst Bacteriol 45, 724-728.

Rainey, F., Weiss, N., Prauser, H. \& Stackebrandt, E. (1994). Further evidence for the phylogenetic coherence of actinomycetes with group B-peptidoglycan and evidence for the phylogenetic intermixing of the genera Microbacterium and Aureobacterium as determined by $16 \mathrm{~S}$ rDNA analysis. FEMS Microbiol Lett 118, 135-140.

Remel (2000). RapID CB Plus System. Lenexa, KS: Remel.

Ruimy, R., Riegel, P., Boiron, P., Monteil, H. \& Christen, R. (1995). Phylogeny of the genus Corynebacterium deduced from analyses of small-subunit ribosomal DNA sequences. Int $J$ Syst Bacteriol 45, 740-746.

Sanders, J. E. \& Fryer, J. L. (1980). Renibacterium salmoninarum gen. nov., sp. nov., the causative agent of bacterial kidney disease in salmonid fishes. Int J Syst Bacteriol 30, 496-502.
Schubert, K., Ludwig, W., Springer, N., Kroppenstedt, R. M., Accolas, J.-P. \& Fiedler, F. (1996). Two coryneform bacteria isolated from the surface of French Gruyère and Beaufort cheeses are new species of the genus Brachybacterium: Brachybacterium alimentarium sp. nov. and Brachybacterium tyrofermentans sp. nov. Int J Syst Bacteriol 46, 81-87.

Seiler, H. (1986). Identification of cheese-smear coryneform bacteria. J Dairy Res 53, 439-449.

Stackebrandt, E. \& Goebel, B. M. (1994). Taxonomic note: a place for DNA-DNA reassociation and 16S rRNA sequence analysis in the present species definition in bacteriology. Int $J$ Syst Bacteriol 44, 846-849.

Stackebrandt, E. \& Prauser, H. (1994). The family Cellulomonadaceae. In The Prokaryotes, pp. 1323-1345. Edited by A. Balows, H. G. Trüper, M. Dworkin, W. Harder \& K. H. Schleifer. New York: Springer.

Stackebrandt, E. \& Schumann, P. (2000). Description of Bogoriellaceae fam. nov., Dermacoccaceae fam. nov., Rarobacteraceae fam. nov. and Sanguibacteraceae fam. nov. and emendation of some families of the suborder Micrococcineae. Int J Syst Evol Microbiol 50, 1279-1285.

Stackebrandt, E., Seiler, H. \& Schleifer, K. H. (1982). Union of the genera Cellulomonas Bergey et al. and Oerskovia Prauser et al. in a redefined genus Cellulomonas. Zentbl Bakteriol Hyg I Abt Orig C3, 401-409.

Stackebrandt, E., Rainey, F. A. \& Ward-Rainey, N. L. (1997). Proposal for a new hierarchic classification system, Actinobacteria classis nov. Int J Syst Bacteriol 47, 479-491.

von Stetten, F., Francis, K. P., Lechner, S., Neuhaus, K. \& Scherer, S. (1998). Rapid discrimination of psychrotolerant and mesophilic strains of the Bacillus cereus group by PCR targeting of 16S rDNA. J Microbiol Methods 34, 99-106.

Suzuki, K., Sasaki, J., Uramoto, M., Nakase, T. \& Komagata, K. (1997). Cryobacterium psychrophilum gen. nov., sp. nov., nom. rev., comb. nov., an obligately psychrophilic actinomycete to accommodate "Curtobacterium psychrophilum" Inoue and Komagata 1976. Int J Syst Bacteriol 47, 474-478.

Takeuchi, M. \& Hatano, K. (1998). Union of the genera Microbacterium Orla-Jensen and Aureobacterium Collins et al. in a redefined genus Microbacterium. Int J Syst Bacteriol 48, 739-747.

Timmins, É. M., Howell, S. A., Alsberg, B. K., Noble, W. C. \& Goodacre, R. (1998). Rapid differentiation of closely related Candida species and strains by pyrolysis-mass spectrometry and Fourier transform-infrared spectroscopy. J Clin Microbiol 36, 367-374.

Tindall, B. J., Brambilla, E., Steffen, M., Neumann, R., Pukall, R., Kroppenstedt, R. M. \& Stackebrandt, E. (2000). Cultivatable microbial diversity: gnawing at the Gordian knot. Environ Microbiol 2, 310-318.

Valdés-Stauber, N., Scherer, S. \& Seiler, H. (1997). Identification of yeasts and coryneform bacteria from the surface microflora of brick cheeses. Int J Food Microbiol 34, 115-129.

Yamamoto, N., Sato, S., Saito, K., Hasuo, T., Tadenuma, M., Suzuki, K., Tamaoka, J. \& Komagata, K. (1988). Rarobacter faecitabidus gen. nov., sp. nov., a yeast-lysing coryneform bacterium. Int J Syst Bacteriol 38, 7-11. 